\begin{tabular}{|c|c|}
\hline Term & Definition \\
\hline $\begin{array}{l}\text { Edge/ } \\
\text { arête }\end{array}$ & $\begin{array}{l}\text { Intersection line of two surfaces of a } \\
\text { same glaciated bedrock form, } \\
\text { parallel to the ice movement and } \\
\text { produced at two different times. }\end{array}$ \\
\hline $\begin{array}{l}\text { Chatter(ing) fractures/ } \\
\text { fractures de broutage }\end{array}$ & $\begin{array}{l}\text { Small curvilinear and nested fractures, } \\
\text { with their concavity facing down the } \\
\text { ice movement. }\end{array}$ \\
\hline $\begin{array}{l}\text { Concave chattermarks/ } \\
\text { broutures concaves }\end{array}$ & $\begin{array}{l}\text { Hollow and arched forms, generally } \\
\text { occuring in series, with a concave } \\
\text { wall facing up-stream and a floor } \\
\text { gently sloping down the ice move- } \\
\text { ment. }\end{array}$ \\
\hline $\begin{array}{l}\text { Convex chattermark/ } \\
\text { brouture convexe }\end{array}$ & $\begin{array}{l}\text { Hollow and arched form, generally y } \\
\text { occurring alone, with a convex wall } \\
\text { facing up-stream and a floor gently } \\
\text { sloping down the ice movement. }\end{array}$ \\
\hline $\begin{array}{l}\text { A type of quarried wall/ } \\
\text { débiture }\end{array}$ & $\begin{array}{l}\text { Sloping lee side of any outcrop plucked } \\
\text { by glacial action. }\end{array}$ \\
\hline $\begin{array}{r}\text { Arcade/ } \\
\text { arcade }\end{array}$ & $\begin{array}{l}\text { A type of quarried wall with a concave } \\
\text { surface, developed along the plane } \\
\text { of weakness of a chatter fracture. }\end{array}$ \\
\hline $\begin{array}{c}\text { Arcature/ } \\
\text { arcature }\end{array}$ & $\begin{array}{l}\text { Quarried wall characterized by juxta- } \\
\text { posed arcades. }\end{array}$ \\
\hline $\begin{array}{l}\text { A type of quarried plane/ } \\
\text { troncature }\end{array}$ & $\begin{array}{l}\text { A quarrymark slightly sloping down- } \\
\text { stream, or a bevelled plane } \\
\text { developed on a weak joint (?) bear- } \\
\text { ing unorganized striations mostly at } \\
\text { its base. }\end{array}$ \\
\hline
\end{tabular}

\section{Size}

Length: decimetric to decametric.

Chord and sine: a few centimetres to a few decimetres.

Chord and sine: a few centimetres to a few decimetres.

Chord and sine: a few centimetres to a few decimetres.

Height: a few centimetres to a few metres; width: longer still.

Height and width: a few centimetres to a few decimetres.

(See arcade.)

Area: a few square metres.

\title{
THE ICE-ROCK INTERFAGE AND BASAL SLIDING PROCESS AS REVEALED BY DIRECT OBSERVATION IN BORE HOLES AND TUNNELS
}

\author{
By B. Kamb, H. F. Engelhardt,
}

(Division of Geological and Planetary Sciences, California Institute of Technology, Pasadena, California 9 i 125 , U.S.A.)

and W. D. HARRISON

(Geophysical Institute, University of Alaska, Fairbanks, Alaska 9970 I, U.S.A.)

Abstract. The glacier bed, where basal sliding occurs, was reached by cable-tool drilling and sand-pump bailing in seven bore holes in Blue Glacier, Olympic National Park, Washington. Basal sliding velocities measured by bore-hole photography and confirmed by inclinometry are unexpectedly low, ranging from 0.3 to $3.0 \mathrm{~cm} /$ day and averaging $1.0 \mathrm{~cm} /$ day. This is much less than about half the surface velocity of $15 \mathrm{~cm} /$ day, which was the sliding-rate expected from earlier deformation measurements in bore holes made by thermal drilling alone.

The glacier bed consists of bedrock overlain by a layer of active subsole drift about $10 \mathrm{~cm}$ thick, which intervenes between bedrock and ice sole, is partially to completely ice-free, and 
is mechanically and visibly distinct from the overlying debris-laden basal ice. The subsole drift participates actively in the sliding process by moving along partially with the ice and by the rolling of its larger clasts when caught between bedrock and moving ice. The underlying bedrock is not definitely seen in bore-hole photographs, but is inferred from drilling performance and penetrometer tests.

A gap, of width up to a few centimeters, often intervenes between ice sole and subsole drift. It may result from ice-bed separation caused by pressurization of the bed by water standing initially high in the bore holes, generating pressures c. $5 \%$ greater than the ice overburden pressure at the bed. The highest sliding velocities occur where a basal gap is present.

The water pressure in subglacial conduits, as indicated by the behavior of bore-hole water levels, was essentially atmospheric in an area of the glacier where the ice was thin (c. $120 \mathrm{~m})$. Wild fluctuations in water level that occur after an initial, precipitous drop reflect variations in water input and in flow capacity of narrow hydraulic connections from bore holes to subglacial conduits. In an area of thicker ice $(c .265 \mathrm{~m})$, the minimum basal water pressure was io bars above atmospheric, and a transient rise of about 6 bars occurred by input of turbid water from the bed after a day of heavy rain. A subglacial stream was encountered by one bore hole and followed by the sounding float for $65 \mathrm{~m}$ down-stream.

The subsole drift is initially so impermeable to inflow of pressurized bore-hole water that there must exist permeability barriers between the drift and subglacial conduits, such as interconnecting areas where ice is in direct contact with bedrock. Because of these barriers, a high interstitial water pressure can be maintained in the subsole drift, which can prevent the basal ice from rapidly invading the subsole drift by regelation.

Anomalously low basal shear stress was present in an area of ice-bed separation, and anomalously high basal shear stress in an area of lowest sliding velocity, reflecting a local stress concentration due to high local resistance to sliding. These conclusions follow from detailed bore-hole tilt measurements near the bottom.

Factors responsible for the smallness of the sliding velocities are (I) high bed roughness due to subsole drift, (2) partial support of basal shear stress by rock friction, and (3) minimal basal cavitation because of low water pressure in subglacial conduits.

Observed conditions at and near the bed do not closely correspond to the idealized state of affairs assumed in theories of sliding. The abundance of rock debris and the lack of a clean ice-rock interface are features quite different from what is assumed in the theories.

A paper reporting much of this work has already been published in Fournal of Glaciology, Vol. 20, No. 84, 1978, p. 469-508.

\section{DISCUSSION.}

R. H. Thомаs: If the base of the ice is debris laden, could there be two sliding interfaces: one at the base and one at the top of the debris-laden layer?

W. B. KАмв: Yes, there might, and there might also be distributed shear within the subsole drift layer. It is an interesting problem to consider at what level or levels the sliding should occur. When there is a basal separation gap, the sliding should certainly be at the level of the gap, but otherwise the choice of level is not so obvious.

S. M. Hodge: If ice is continually invading the subsole drift and being melted within the drift, what happens to the water produced if this drift is sealed off from the active drainage system of the glacier? 
КАмв: The water remains where produced, as pore water in the layer of subsole drift that is growing. The pressure in this pore water inhibits ice invasion of the subsole drift layer and allows this layer to grow by bottom melting.

Hodge: Could you comment on why the sliding velocity increased when the water level in the bore hole dropped?

KАмB: Possibly the increase in sliding speed resulted in increased ice-bed separation, which opened up a connection to a subglacial channel and thus allowed the bore-hole water to drain away. There is certainly a problem of what is cause and what is effect in the correlation of the two events, if the correlation is not simply accidental.

L. A. Lliboutry: Are you sure that there is not a continuous inflow of water into your bore hole along its walls, because glacier ice is not perfectly impervious? Have you tried to pump off the water in the bore hole?

KАMB: For bore holes in firn (and all but two of our holes were in firn), there is continuous inflow of water from the firn. With the bore-hole television we can see it enter and cascade down the hole. I doubt that there is any significant inflow through the ice walls. We have pumped water out of some bore holes with an air-lift pump, at a limited rate, and we have carried out several experiments in which water was pumped into the holes and the response was followed. Hermann Engelhardt has a paper on this which will appear in a forthcoming issue of Zeitschrift für Gletcherkunde und Glazialgeologie.

Lliboutry: Can the value of the ice pressure not actually be higher than its mean value $\rho g h \cos \alpha$ as a consequence of a horizontal variation of the shear stress? This would give perhaps $\mathcal{N}=\rho g h \cos \alpha-p$ zero instead of negative.

Камв: We do not think that the pressure of the base of the ice could generally be increased by this effect. More likely are local increases representing stress concentrations over the stoss surfaces of bedrock obstacles. Such an increased ice pressure may explain why the water in one bore hole $(\mathrm{Y})$ never dropped from its high initial level.

Lliboutry: Have you any idea of the source of the basal drift you found?

Камв: The debris is derived from the local bedrock, which is relatively homogeneous, so that unique "tracer" lithologies whose source area can be pinpointed are not available.

W. H. MATHEws: In your model of shearing at the base of the debris layer, can you conceive of the shear surface from time to time or place to place shifting up to the top of the debris layer, at its contact with clear ice above? Shearing might then provide heat to maintain a - water layer here, and isolate a mass of frozen debris below.

Kамв: This is conceivable. The subsole drift does appear locally to contain some interstitial ice, which might have originated in this way. Geothermal heat would of course tend to eliminate it.

R. J. Rogerson: Did you make any observations on the character of pebbles at the bottom of the holes? Particularly, is there any difference in roundness of stones beneath the firn and those beneath the holes further down the glacier.

КАмв: We study each bailer haul (as well as the bottom photographs) with an interest in the answer to your question. Some of the clasts, particularly the larger ones, show the effects of contact with the bed (rounding, striated surfaces), but most are quite angular and thus appear locally derived. 
J. Weertman: You suggest that a boulder layer, such as the one you observed under Blue Glacier, may exist under most glaciers. But the very small sliding velocity that you measured for Blue Glacier is surely exceptional. The seasonal velocity fluctuations measured on many glaciers give an order-of-magnitude estimate of sliding velocities and these velocities are large compared with the Blue Glacier sliding velocities. If the Blue Glacier sliding velocity is exceptional, then perhaps its basal boulder layer-whose existence is the presumed cause of the low sliding velocity-is also exceptional.

Kамв: The sliding velocities found in Blue Glacier may well be similar to the wintertime sliding velocities of glaciers generally, which cannot be inferred from the seasonal fluctuations. It seems likely that a basal debris layer is a rather general feature of glaciers, and that it may limit the wintertime sliding to velocities of a few centimetres per day. The lubrication mechanism that I described may account for a summertime increase in sliding velocity when it occurs.

G. S. Boulton: I am not convinced that you have found bedrock in your holes. There are many case studies in which cable-tool drilling has proved incapable of penetrating a very hard till, which is quite often more difficult to penetrate than the bedrock from which the till is derived. I suggest that the soft layer could equally well be interpreted as a deforming layer lying above a relatively rigid consolidated lower layer. The relative uniformity of the "active subsole drift" would support this idea. If this latter is correct it would explain the inconsistency in the sliding estimates produced from inclinometry and bore-hole photography, and that there is no fixed datum at the bottom of the holes but that the subsole drift is deforming continuously.

The idea of an open-work gravel beneath the glacier, which allows ice to penetrate it to a substantial depth does not seem compatible with most subglacial observations of sediment, which show a matrix between large particles and no significant ice penetration.

The pressure drop you observed is similar to one we observed after several days in subglacial sediments in Iceland. There we believe it to be associated with consolidation of the sediment. Could that not also be true in your case?

Kамв: From our experience we do not believe that the cable tool would have more difficulty penetrating till than bedrock under Blue Glacier. We believe that the abrupt cessation of drill penetration indicates that we encounter bedrock in our bore holes, but, as I said, this is not proven. We give the detailed arguments for these conclusions in our paper in the fournal of Glaciology. As also explained in detail in this paper, we think that our measurements of basal sliding by bore-hole photography are consistent with those from surveying and inclinometry to within the not inconsiderable errors involved in these methods, but in any case, the agreement or disagreement between these measurements does not help distinguish between bedrock or rigid till as the substrate for the active subsole drift.

Penetration of ice into basal rock debris (mixture of gravel, sand, and finer particles) is seen in some of our bore-hole photographs and also in some subglacial tunnels, specifically Bondhusbreen, Glacier d'Argentière, Mer de Glace, and Blue Glacier.

Consolidation of subglacial sediment would reduce its permeability and therefore inhibit the loss of water from a bore hole reaching the bed. Application of water pressure would not cause permeable sediments to consolidate. You might think that the opening of a basal gap between ice and subglacial debris could result from consolidation of the debris, but we think that more probably it results from local uplift of the ice mass under water pressures greater than the overburden pressure of ice. The bore-hole water can then escape through the gap thus opened, and the bore-hole water level therefore drops. 